\title{
Sedimentary Characteristics and Lithological Trap Identification of Distant Braided Delta Deposits: A Case on Upper Cretaceous Yogou Formation of Termit Basin, Niger
}

\author{
Zhao Ning $^{* 1}$, Gao Xia ${ }^{1}$, Huang Jiangqin ${ }^{2}$, Chen Zhongmin ${ }^{1}$, and Zhang Guangya ${ }^{1}$ \\ ${ }^{1}$ PetroChina Research Institute of Petroleum Exploration and Development, 100083 Beijing, China \\ ${ }^{2}$ CECEP L\&T Environmental Technology, 100085 Beijing, China
}

\begin{abstract}
Lithological trap identification in thin sand and thick shale layers is still a challenge for hydrocarbon exploration. Based on the high-resolution sequence stratigraphy theory and the establishment of high-resolution sequence stratigraphy framework with seismic-well tie, the dynamic deposition process of braided delta sands on late Cretaceous Yogou formation has been analyzed on 62 wells in passive rifting Termit basin with multi-stages depressions and reversals. (1) Six kinds of sedimentary microfacies and three major reservoir sands with multi-stages vertical stacking and lateral migration are in late Cretaceous; (2) Based on accommodation space/Sediments supply change and depositional progress, sedimentary facies distribution evolution has been done according to sands thickness statistics of sedimentary micro-facies, and narrow-time seismic attributes and slices analysis, multi-sources braided delta depositional model has been concluded; (3) Based on source rock and caprock evaluation, with reservoir sands distribution and faults impact on Yogou formation of Termit basin, four types of traps, including structure-lithology, Structure-strata, stratigraphic and lithology are concluded. Traps influencing factors, i.e., structure geometry, sands distribution, paleotopography, stratigraphy cycling, sand/shale lateral connection, reservoir quality and so on, have different impacts on these traps, and different lithologic-stratigraphy traps have different exploration risks. Structure geometry and sands distribution are very important for the structure-lithology traps; structure geometry and paleotopography are the key factors in Structure-strata traps. Sands distribution and reservoir quality can be focused on lithology traps. Moreover, paleotopography and sand/shale lateral connection are significant on stratigraphic traps. Therefore, different hydrocarbon accumulation types of lithological traps have been established.
\end{abstract}

\section{Introduction}

As M.c.Pherson [1] mentioned, braided delta is rich in sands and gravels, formed by braided rivers system influxing into stagnant water, and there are many classification schemes about braided delta models, i.e., shallow or deep water kinds [2], gentle or steep slope types [3], progradation or retrogradation sorts [4-6], and distant or nearby models [7-8] with no consistency. Different evolution stages of sedimentary basin cause the different controlling factors in deposition progress of braided deltas.

Since the 1970's, the exploration level of most hydrocarbon basins has been so high in all around world, and most of traps have been found in relatively regular anticlines. The next step is to find newly subtle traps, i.e. lithologic stratigraphy traps. Carl (1880) found various, different shape, unknown, and unpredictable non-anticline reservoirs [9]. Following "non-structural trap" (Wilson, 1934[10]) and "stratigraphic trap"
(A.I.levorsen, 1936[11]), A.I.levorsen [12] pointed out subtle trap concept systematically, and M.T.Halbouty (1972) \& Zhang Wei [13] included stratigraphic trap, unconformity trap and paleo-topographic trap into subtle traps, but used rarely at that time. Professor Jia Chengzao (2003) suggested "lithologic stratigraphy trap" instead of "subtle trap" in 2003. For reasons of the difficulty of the trap identification, irregular shape, trap scale, low seismic technology accuracy, and high risk of oil/gas exploration, most of overseas oil company do not willing to explore litho-strata traps.

For thin sand and shale interlayers in braided-river delta front deposits, based on high-resolution sequence stratigraphy (HRSS), this text discusses sands progradation and retrogradation through the dynamic depositional progress, considering about tectonic evolution of Termit basin, sedimentary micro-facies characteristics of the 3rd member of Yogou formation, sands or shales thickness distribution of micro-facies statistics, multi-provenance supply sedimentary model on

\footnotetext{
* Corresponding author: author@e-mail.org +861083598042. 
upper Cretaceous period, sands distribution evolution with seismic attributes prediction and well logs. Moreover, this text also evaluates source-reservoir-caprock condition on TOC, HI, and Kerogen maturity for source evaluation, sand thickness and porosity distribution for reservoir evaluation, and shales density, thickness, porosity and permeability for caprock evaluation. And then it shows favourable areas on Fana uplift-Yogou slope southeast Termit basin for depression tectonic background, slope paleotopography, near hydrocarbon centre, sand-shale interlayer associations, and discusses influencing factors about structure geometry, paleotopography, sands distribution, sand-shale lateral connection, reservoir quality on four kinds of lithologic traps, i.e., structure-lithology, Structure-strata, stratigraphic and lithology traps. Finally, this text concludes the hydrocarbon accumulation model of four kinds of lithologic traps in upper Cretaceous period of Termit basin, and predicts risks and targets of lithologic traps for great support to oil-gas exploration of Termit basin.

\section{Geological Settings}

As we know, Africa plate is one of six plates in the global, composed of four cratons, including west Africa, east Africa, Congo and Kalahair cratons. It was formed during Gondwana supercontinent convergence in $550 \mathrm{Ma}$ ago, and separated by south America plate in early Cretaceous epoch. Three craton basin groups include north inter-craton, north craton margin and south inter-carton basin groups, five rift systems include Karoo (Paleozoic), west Africa, central Africa (Mesozoic), east Africa and red sea (Cenozoic) rift systems; three rift basin groups, i.e. west Africa, central Africa and east rift basin groups, three passive margin basin groups, i.e. west Africa, east Africa, and northeast Africa passive margin basin groups, and one north African foreland basin group. From IHS statistics, most of oil fields locate on three RBGs in Cretaceous period, and gas fields are around three PMBGs. Termit basin in Niger locates on the west $\mathrm{RBG}$, and is divided by west Africa RS.

In late Cretaceous epoch, serval tectonic settings including two depressions, i.e. Dinga and Moul depression; three uplifts, i.e. Soudana, Fana, and West Termit uplift; two fault zones, i.e. Dinga and Araga garben fault zone; three slopes, i.e. Yogou, Trakes and eastern Termit slope, locate on Termit basin, caused by the dextral strike slip traction belt along eastern Termit slope, Fana low uplift and Yogou slope area, and most of faults are in NW-SE direction, caused by west Africa RS and influenced by central Africa RS. According to the tectonic evolution of Termit basin, Termit basin went from depressing to rifting tectonic movement from Cretaceous to early Paleogene period. In middle Cretaceous epoch, Neo-Tethys and south Atlantic oceans invaded into Dinga and Moul depression, thick and dark shales distributed in the whole area, interbedded with thin and fine sands deposits with retrograding sequence stratigraphy stacking pattern, especially in YS1 and YS2 sub-formation. In late Cretaceous epoch, two oceans retreated and disappeared from Termit basin, with sands and shales interlayers in the whole area, with retrograding sequence stratigraphy stacking pattern. Especially in Maastrichtian age, large thickness of braided river channel sands overlaid vertically in Madama formation, indicating relatively high hydraulic power in sediments deposition (Fig.1)

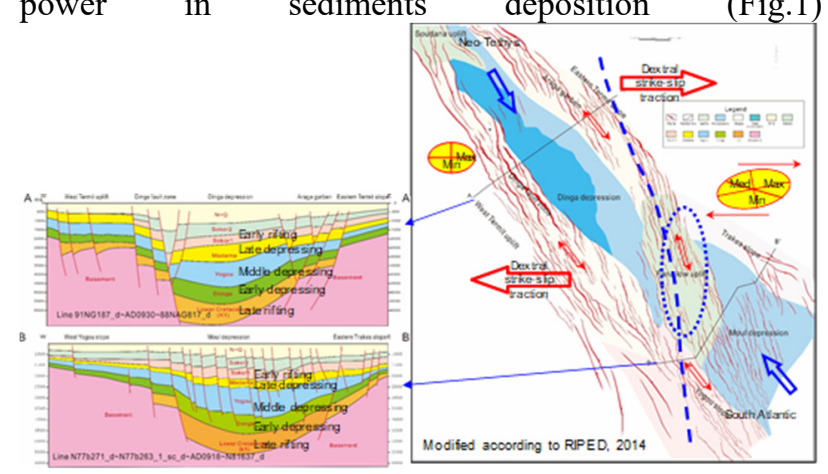

Fig.1. Tectonic settings and structure sections of Termit basin (the left figures show structure sections across the north Dinga sag and south Moul sag; the right figure shows Termit basin structural setting and tectonic stresses during Cretaceous period, including two depressions, i.e. Dinga and Moul depression; three uplifts, i.e. Soudana, Fana, and West Termit uplift; two fault zones, i.e. Dinga and Araga garben fault zone; three slopes, i.e. Yogou, Trakes and Eastern Termit slope, according to RIPED2014)

\section{High-resolution sequence stratigraphy framework}

In early Cretaceous period, Termit basin went through thick alluvial fan-river sands during rifting period continental environment from Valanginan to Albian stage in $\mathrm{K} 1$ formation with an intact the $2^{\text {nd }}$ grade sequence. In late Cretaceous period, it became a limited-sea basin in Donga-Yogou-Madama formation from Cenomanian to Masstrichtian stage. In the early epoch, Neo-Tethys and south Atlantic oceans invaded into Dinga and Moul depression, thick and dark marine shales distributed in the whole area, interbedded with thin and fine sands deposits with retrograding sequence stratigraphy stacking pattern, especially in Turonian stage [15] Donga formation. In the late epoch, two oceans retreated and disappeared from Termit basin, with sands and shales interlayers distributed in the whole basin, with retrograding sequence stacking pattern. Especially in Maastrichtian age, thick braided river channel sands overlaid vertically in Madama formation, indicating relatively high hyd raulic power in depositional progress (Fig.2). Therefore, another the 2nd grade sequence includes low-stand system tract (LST) in early Donga formation, transgressive systems tract (TST) from middle Donga to early Yogou formation, high-stand systems tract(HST) from late Yogou to late Madama formation (Fig.2). There are two unconformities between K1 and Donga formation, between Madama and Sokor1 formation, and they are the boundary between lower Cretaceous, upper Cretaceous e poch and Paleogene period. Combined with logging data, choosing high continuity and high amplitude seismic axis which can be searched for whole area in Sokor and Yogou formation 
(Fig.2), the $3^{\text {rd }}$ grade sequence stratigraphy can be further divided. Sokor1, sokor2 and sokor3 sub-formations can be classified in Sokor formation in the $3^{\text {rd }}$ grade, and ES1-ES5 members are identified in sokor1 sub-formation. YS1, YS2 and YS3 sub-formations are divided in the 3rd grade, and YS3-1-YS3-3 members can be identified in YS3 sub-formation. High or low amplitude caused by impedance difference reflects sand-shale deposits homogeneity, the continuity and frequency of seismic axis gives the information about sands continuity of lateral and planar distribution, and the hydrodynamic condition in deposition process.According to HRSS and seismic and logging data, considering sands progradation and retrogradation dynamic process, Yogou formation are divided into three sub-formations, showing coarsening upwards deposits, with funnel shape gamma (GR) and resistivity (RT) logs, and from low to high amplitude and frequency seismic changes, which indicates getting higher hydrodynamic power upwards. The upper YS3 sub-formation deposits marine braided delta front interlayers, with medium-low GR and medium-high RT logs, corresponding with high amplitude, medium continuity and medium-high frequency seismic characteristics; the middle YS2 sub-formation is grey or dark grey thick marine shales, interlaid with thin sands layers, with high GR, low RT logs, corresponding with medium-high amplitude, high continuity and high frequency seismic characteristics; the lower YS1 sub-formation has dark grey thick marine shales, without sand layers, with high GR, low RT logs, corresponding with high amplitude, high continuity and medium frequency seismic responses. Furthermore, YS3-1 / YS3-2 / YS3-3 member (Fig.2), corresponding to three sand group can be partitioned in the main target layer YS3 sub-formation, and sands in three members are unstable. Different BLC change of depositional layers can be caused by different paleotopography in depression period. Progradation and coarsing upwards deposits are located on upper slope, near provenance supply, which is sandy upwards and shaly downwards; Retrogradation and fining upwards deposits are located on lower slope, near depositional centre, which is shaly upwards and sandy downwards.

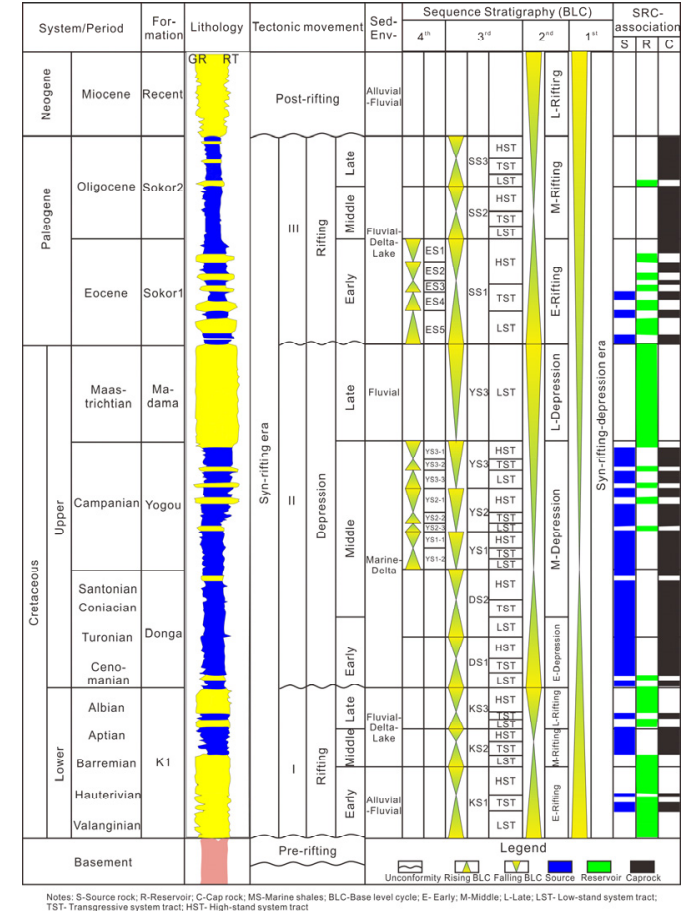

Fig.2. Comprehensive sequence stratigraphy framework of Termit basin (Notes: LST - low-stand system tract; TSTtransgressive system tract; HST - high-stand system tract; BLC - base level cycle; $\mathrm{S}$ - source rock; $\mathrm{R}$ - reservoir; $\mathrm{C}$-cap rock)

\section{Sedimentary facies and sands distribution}

\subsection{Sedimentary facies classification}

Based on HRSS division and correlation, with seismic interpretation results, top Yogou structure, bed thickness and paleotopography are analyzed. Two sags, two uplifts, two fault steps and two slopes are the structure characters of Termit basin, and the main Dinga sag with Dinga fault step in west and Araga graben in east, the secondary Moul sag with Yogou slope in west and Trakes slope in east, and Soudana uplift in north, Fana uplift between two sags. Tethys ocean in north is unconnected with Dinga sag, the Atlantic Ocean in south connected with Moul sag during Campanian stage Yogou formation, forming a limited sea and continental provenance depositional environment. Provenance in YS3 sub-formation came from the east, the northwest and the southwest, and continent sands supply was relatively more than a vast sea environment (Zhao Ning, 2015). Marine - braided delta deposits, including braided delta front sands and seashore shales, were in Yogou formation of Termit basin, using 62 wells logging, mud logging and $11607 \mathrm{~km}^{2}$ 3D seismic data. Sedimentary facies include submarine distributary channel (SDC), mouth bar (MB), sand sheet (SS), coast shale (CS) and bathyal sea shale (Fig.3).

Considering about well logs, mud logs, seismic response and vertical stacking pattern of shales and sands, braided delta, lacustrine, and marine deposits were identified, three kinds of sands and three kinds of shales can be good source rock-reservoir-cap rock association. Submarine channels (SC) are medium - fine sands, with 
bell, gear or box shape in GR, and finning upwards; they are continuous, strong - medium amplitude, medium frequency, with flat top and convex bottom vertical to source direction and belt shape parallel to source direction in seismic sections (right Fig.3). Mouth bars (MB) are medium - fine sands, with funnel shape in GR, and coarsening upwards; they are discontinuous, strong medium amplitude, medium frequency, with convex top and flat bottom along with short elliptical axis and elongated shape along with long elliptical axis in seismic sections (right Fig.3). And sand sheets (SS) are fine sands to slits, with finger or spiny shape in GR; they are good continuity, week amplitude, medium-strong frequency, always multi-periods sands overlaid vertically, with belt shape in seismic sections (right Fig.3). Considering about sands thickness of vertical stacking patterns, submarine channels and mouth bars can be further divided into main sands and sands flank, with different source supply distribution and hydraulic power in Yogou formation.

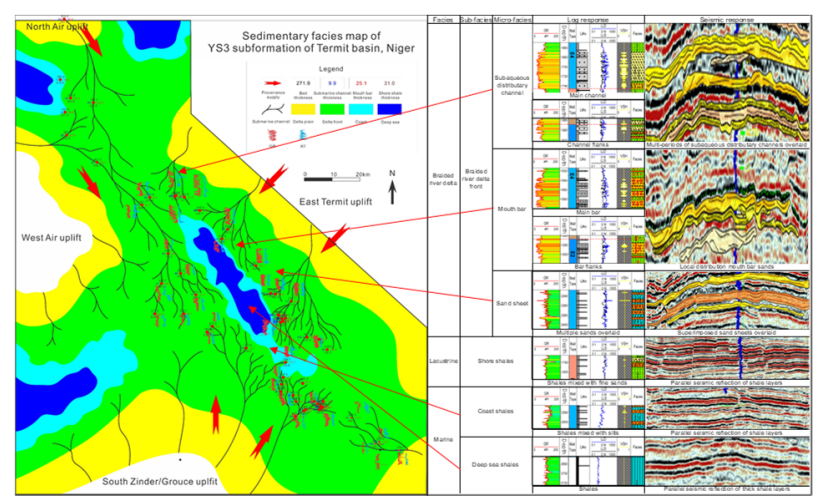

Fig.3. Sedimentary facies distribution and well-seismic temple of Termit basin (left figure: sedimentary facies distribution of Yogou formation in Termit basin using well logging and seismic data; right figure: well seismic templates in Termit basin.)

Moreover, coast shales are always shales mixed with fine sands or silts, and shallow marine or deep marine shales are relatively cleaner with little sands, mixed with silts sometimes. Compared with lacustrine shales in Sokor1 formation, marine shales in Yogou formation are thicker and darker colour (right Fig.3 black or dark grey colour), indicating a relatively quiet depositional environment compared with Eocene continental tectonic setting (right Fig.3 light grey or off-white colour). Considering about the depressing structure in Campanian stage, TWT map can give a brief view about paleotopography of Yogou formation. Provenance supplies are come from east, northwest and southwest directions (left Fig.3). Based on the sedimentary facies analysis and bed thickness, all micro-facies thickness statistics of 62 wells in YS3 sub-formation of seven Termit basin sub-structures, i.e., two uplifts, two fault steps, two slopes and lake Chad, vertical reservoir caprock combination condition can be analyzed. Yogou slope, Fana uplift and Soudana uplift are the major sediments discharging area, average cumulative bed thicknesses of these areas are more than 300m, Dinga fault step, Araga graben and west Termit platform and southern submarine channels are relatively small (left Fig.3). According to the average cumulative submarine channel thicknesses distribution, Fana uplift is larger than Araga graben, more than 140m, and far more than other Termit sub-structures (left Fig.3), indicating the main provenance supply in YS3 sub-formation comes from east Termit basin, and sands goes from Araga graben to Fana uplift. The secondary provenance supply comes from southwest Yogou slope, most of sands are sand sheets (left Fig.3), with average cumulative thickness nearly 70m, much lower than Fana uplift (Table.1).

From well sections vertical to provenance supplies direction (left Fig.4), most of braided delta front sands goes from eastern Termit slope to Dinga and moul sag, with multiple supplies and periods submarine channels, and little sands in south moul sag (lower right Fig.4). From the west section, provenance supply comes from north western Soudana uplift in late Campanian stage and joins together with another sands supply from western Termit basin in early Campanian stage. They go thinner and extinguishing very quickly in a short distance. South provenance supply comes from Yogou slope (upper right Fig.4).

Table 1. Sedimentary micro-facies sand thickness statistics of YS3 sub-formation in blocks of Termit basin (notes: Bed-strata layers of YS31, YS32, YS33, SC-submarine channel, MB-mouth bar, SSS-sand sheet sands, CS-coast shale.)

\begin{tabular}{|c|c|c|c|c|c|c|c|c|c|c|c|c|c|c|c|c|c|c|c|c|c|}
\hline \multirow{2}{*}{ Thickness } & \multicolumn{3}{|c|}{ Yogou slope (17) } & \multicolumn{3}{|c|}{ Fana low uplift (8) } & \multicolumn{3}{|c|}{ Soudana uplift (9) } & \multicolumn{3}{|c|}{ Dinga fault step (6) } & \multicolumn{3}{|c|}{ Araga garben (7) } & \multicolumn{3}{|c|}{ Termit west uplift (3) } & \multicolumn{3}{|c|}{ Lake Chad (4) } \\
\hline & $\max$ & $\min$ & average & $\max$ & $\min$ & average & $\max$ & $\min$ & average & $\max$ & $\min$ & average & $\max$ & $\min$ & average & $\max$ & $\min$ & average & $\max$ & $\min$ & average \\
\hline $\operatorname{Bed}(\mathrm{m})$ & 470.3 & 177.0 & 324.0 & 506.4 & 354.5 & 423.9 & 553.6 & 306.5 & 418.8 & 342.7 & 190.8 & 265.2 & 315.8 & 198.6 & 243.9 & 308.0 & 271.9 & 290.6 & 288.9 & 247.3 & 266.8 \\
\hline $\mathrm{SC}(\mathrm{m})$ & 110.1 & 10.4 & 52.6 & 186.7 & 23.0 & 141.9 & 73.7 & 0.0 & 35.9 & 81.7 & 9.0 & 34.1 & 154.5 & 13.5 & 63.6 & 31.1 & 6.5 & 15.9 & 138.2 & 35.4 & 67.4 \\
\hline $\mathrm{MB}(\mathrm{m})$ & 72.2 & 8.6 & 31.6 & 87.1 & 36.7 & 58.5 & 102.7 & 9.0 & 38.6 & 53.5 & 4.1 & 16.0 & 72.6 & 14.5 & 35.0 & 49.6 & 15.5 & 30.1 & 35.1 & 9.5 & 17.9 \\
\hline $\mathrm{SSS}(\mathrm{m})$ & 108.8 & 13.4 & 70.1 & 103.0 & 25.9 & 75.3 & 102.4 & 23.5 & 55.0 & 46.1 & 10.9 & 34.9 & 54.7 & 13.0 & 35.5 & 45.9 & 25.8 & 34.2 & 42.0 & 8.1 & 25.7 \\
\hline $\operatorname{CS}(\mathrm{m})$ & 282.9 & 90.3 & 169.9 & 188.4 & 116.8 & 148.4 & 371.0 & 219.5 & 288.2 & 292.3 & 95.0 & 180.4 & 142.1 & 68.5 & 109.9 & 226.1 & 181.4 & 210.5 & 209.2 & 122.3 & 156.0 \\
\hline
\end{tabular}



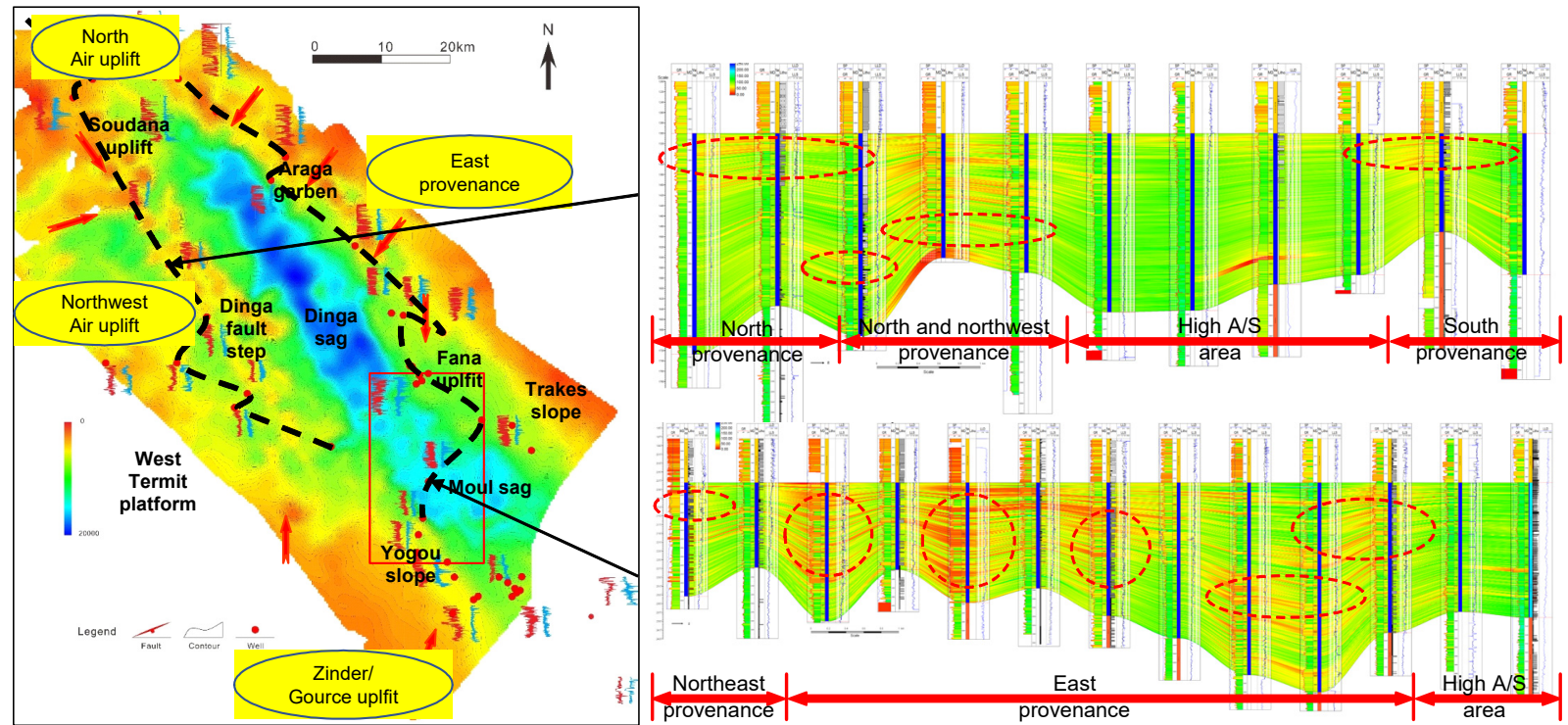

Fig.4. Bed thickness of Yogou formation and sands correlation in Termit basin (left figure shows bed thickness of Yogou formation in time scale; upper right figure is sands correlation through Soudana uplift-west Termit uplift-Dinga faulted steps; lower right figure is sands correlation through Araga graben-Fana uplift- Yogou slope)

\subsection{High resolution seismic attribute analysis}

With the high resolution of seismic data lateral prediction and well logging vertical prediction, sedimentary micro-facies sands distribution in each zone can be predicted by seismic attributes, slices and seismic inversion. And as we know, seismic resolution is the key factor to study the sequence stratigraphy and sedimentology by seismic data, and the maximum vertical resolution is $1 / 4$ wavelet length [16]. The average acquisition accuracy of seismic data in study area is $50-60 \mathrm{~Hz}$, and the seismic velocity in Yogou formation of upper Cretaceous epoch is $1900-2300 \mathrm{~m} / \mathrm{s}$. Therefore, the minimum identified sands thickness is $31.67-46 \mathrm{~m}$. This resolution is far less than the required accuracy of lithology traps study. However, the geologic statistics of sands distribution in each horizon with seismic attributes slices can show sand distribution evolution both vertically and laterally.

Seismic attributes can give us information about sand-shale distribution, sedimentary facies, fluid filling condition or reservoir properties from seismic data directly or extracted by digital conversion, and more truthful than seismic convention for less manual operation. There are multiple types of seismic attributes, such as amplitude, frequency, phase, energy, waveform and so on. Some of them are sensitive to reservoir lithology [17], some of them are sensitive to porosity liquid [18], some are useful for abnormal body underground [19-20], others can reflect sedimentary cycles [21] in the geological history. Moreover, sedimentary face can be got in one seismic attribute or multiple seismic attributes together [22]. Amplitude attribute is useful for quick change with thin sand-shale interlayers both vertically and laterally in braided delta front deposits [23]. Such as Yogou 3D area in south Termit basin, with the same time interval from 20ms up top Yogou to 50ms below top Yogou, average energy, RMS and arc length attributes show different results.
Average energy is less sensitive than RMS, and its algorithm can't give impedance difference between thin sands and shale interlayers. Arc length is more sensitive than RMS, highlights on sandy area. However, wave length is not stable and usually shows abnormal reflection (highlights) in faults area. These highlights are along with faults direction, misleading as sands distribution. Therefore, RMS is more effective method for sands distribution prediction for its amplifying the difference of thin sands and shale interlayers impedance, and not relate to sample interval, avoiding faults impact on sands distribution prediction. Seismic-well tie is useful for sands distribution prediction. With sedimentary micro-facies sand thickness in 62 wells in each member of YS3 sub-formation, and RMS seismic attribute distribution, sands distribution prediction can be done. Seismic attributes include profile attributes, horizon attributes and $3 \mathrm{D}$ attributes, horizon attribute are usually used for sands distribution prediction. In high-resolution sequence stratigraphy framework of the 5 th grade (zone level), short time interval $(1 / 4 \lambda)$ of RMS can show quick evolution of braided delta front sands distribution both in lateral and in planar. Such as submarine channels in Fana uplift show frequently lateral migration and vertical progradation. These submarine channel belts are near $110 \mathrm{~km}$, with area of $355 \mathrm{~km}^{2}$ in YS3-1 zone, and changed into single submarine channels, with decreased length $58 \mathrm{~km}$, and reduced area of 82.4 $\mathrm{km}^{2}$ in YS3-3 zone. Another useful method is short time interval RMS slices. It not only shows braided delta front sands progradation and retrogradation evolution, but also indicates strong or weak provenance supply in different stages. Such as six micro-seconds RMS slices in Yogou slope (Fig.5), combined with sedimentary facies analysis in 17 wells of Yogou 3D area, provenance supplies come from southwestern and north eastern of Yogou 3D area, and they get together in centre area. Provenance supply from north eastern are more sufficient than south eastern in early YS3 sub-formation, multi-periods of submarine 
channels in north eastern area are more than $35 \mathrm{~m}$, and less than $20 \mathrm{~m}$ in southwestern area, and most of sands are assembling in centre area, the thickness is more than $70 \mathrm{~m}$, by reason of multi-periods of overlaid submarine channel sands discharge with less hydrodynamic power.

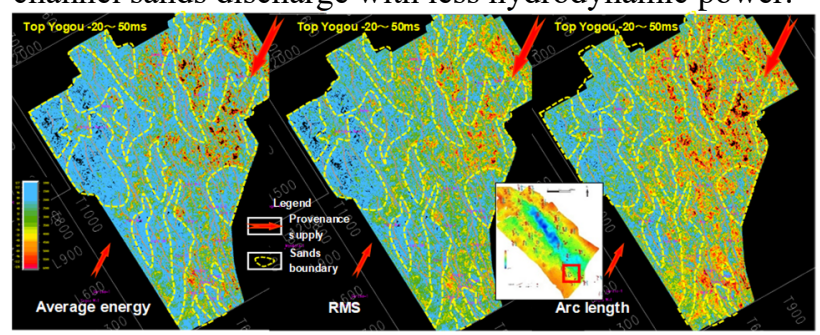

Fig.5. Comparison of average energy, RMS and arc length from $20 \mathrm{~ms}$ up top Yogou to 50ms below top Yogou in Yogou 3D, south Termit basin (the same time widow, different results by different seismic attributes)

However, provenance supply from south eastern are more sufficient than north eastern in late YS3 sub-formation (Fig.6). This result can be testified by wells section from southwest to northeast in Yogou 3D area, sedimentary facies and provenance supply direction changes in different braided delta front deposition. Sand sheets come from northeast to southwest direction in YS3-3 zone, then submarine channels and mouth bars come from southwest to northeast direction in YS3-2 zone, and submarine channels and mouth bars come from near north direction.

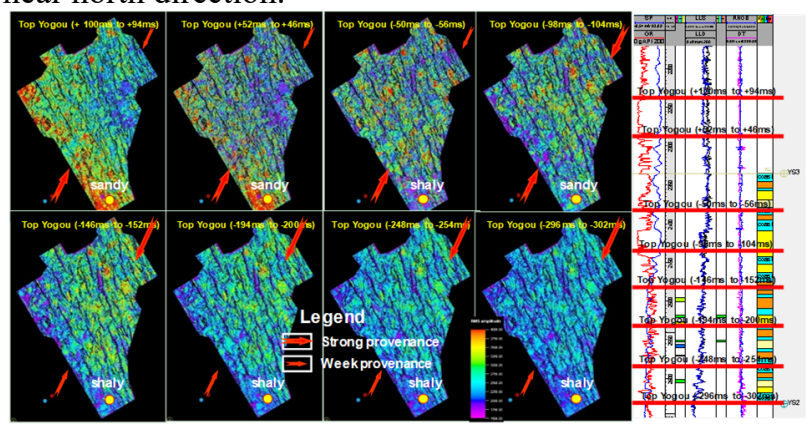

Fig.6. Six micro-seconds seismic-well tie RMS attribute slices of YS3 sub-formation in Yogou slope, south Termit basin (from the bottom to the top, provenance supply changed from northeast in YS3-3 zone and from southwest in YS3-1 zone)

Moreover, isochore RMS slices can give sands evolution both vertical in profiles and lateral in plane distribution, testified by well data. Especially for delta front or braided delta front deposits with obvious sands progradation and retrogradation, RMS slices are more sensitive than other seismic attributes in the study area. For example, in Fana uplift of east Termit basin, ten isochronous RMS strata slices of YS3-2 zone, near 3m in each interval, show sands migrating from the east to the west from the bottom to the top, and an intact BLC cycle change with sandy in lower layers, shaly in above layers, and sandy again in upper layers vertically.

Considering sedimentary sands distribution between Fana uplift and Yogou slope, dual- source with different intensity of braided delta deposit model is established (Fig.7), and northeast provenance supply was stronger than the southwest, and they joined together in Moul sag, the central area, in the form of mouth bars and sand sheets. With braided river channels flowing into deep sea area, river channels changed from distributary channel in braided delta plain above water level, into subaqueous distributary channel in braided delta front under water level, and submarine channels in distant braided delta front, where most of sands are discharged of mouth bars or sand sheets. From the evolution of braided delta channels, little channels were in the early Cretaceous period, and more and more channels were in late Cretaceous period as sands progradation from the northeast and southwest area, and channels went longer distance with large distribution, by multiple periods of channels vertical superposing and later migrating.

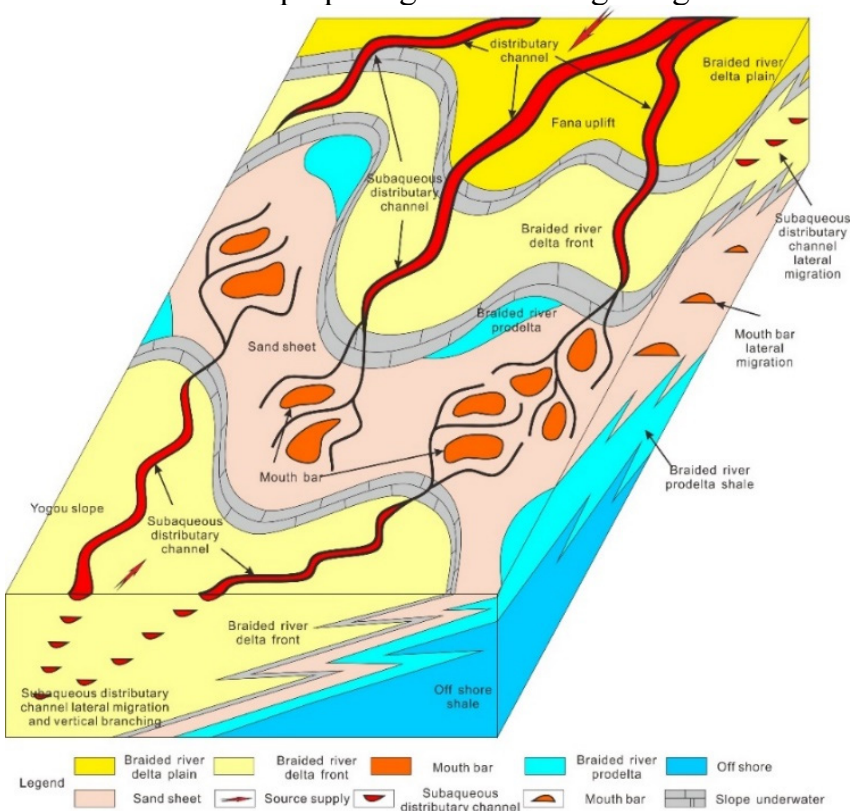

Fig.7. Sedimentary model of Fana uplift-Yogou slope of YS3 sub-formation in Termit basin (multi-provenance supply with different strength, showed submarine channels lateral migration and vertical change.)

\section{Lithologic trap identification}

\subsection{Source rock evaluation}

Mature hydrocarbon source rock and fertile hydrocarbon supply are the precondition and requirement of large scale lithologic traps relied on. In different periods of serval types of oil and gas basin [24], the threshold of maturity of source rock is $65^{\circ} \mathrm{C}$. The buried depth of Yogou formation in Termit basin is normally 2300$2800 \mathrm{~m}$, and the average geothermal gradient is $3.1-3.4^{\circ} \mathrm{C}$ $1100 \mathrm{~m}$, so the ground temperature is more than 71.3-95. $2^{\circ} \mathrm{C}$. Therefore, source rock in Yogou formation were mature and in the range of large hydrocarbon generation. Based on shale samples of 16 wells in Termit basin, TOC (Total organic carbon) and HI (Hydrocarbon index) showed Dinga sag in centre and Moul sag in southeast were hydrocarbon kitchens of Termit basin with high hydrocarbon-generating density and good oil/gas shows. From the maturity distribution of source rock, shales in Dinga sag with deeper buried depth was mature, and over-mature with gas bearing in Dinga sag 
centre. However, shales in Moul sag was in early-mature or mature stage. From the oil test results of drilled wells in Yogou formation, most of oil in structure traps was discovered on Fana uplift and Yogou slope. Therefore, an oil accumulation model of hydrocarbon supply in two sags with near source accumulation was established (Fig.8)

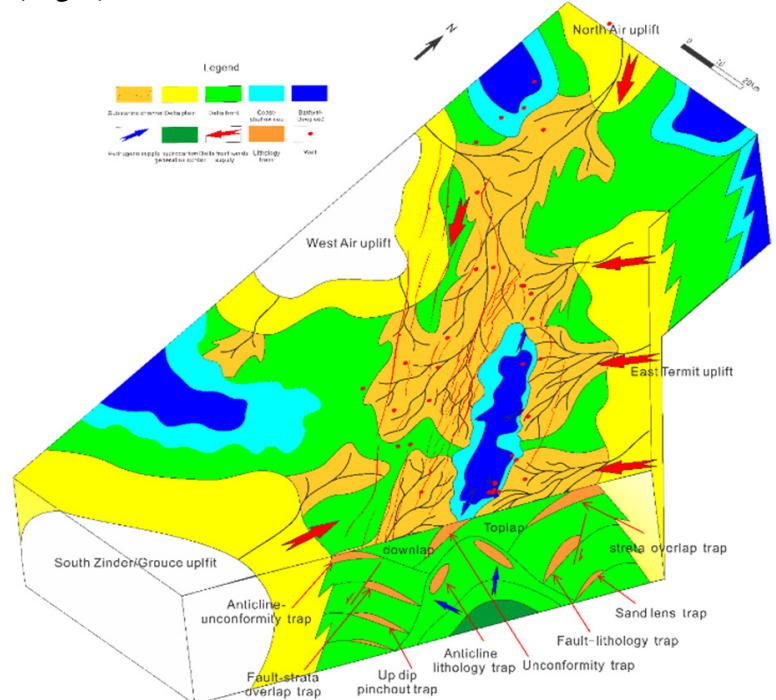

Fig.8. Reservoir model of lithologic traps (lithologic traps on Fana uplift and Yogou slope are stratigraphic

overlap/toplap/downlap reservoirs, structural or fault lithology reservoirs, and sand lens pinch-out reservoirs)

\subsection{Cap rock evaluation}

Cap rock is more important in effective lithologic traps forming. Shales should go through serval diagenetic evolution progresses [25], and then has the sealing ability. This ability is more relevant to the diagenesis, the deeper buried depth, the higher shales diagenetic degree, and the displacement pressure goes higher to reach the oil/gas sealing ability [26]. The parameters for evaluating the sealing ability are porosity, permeability, density, specific surface area, microscopic pore structure and so on. According to shales sealing ability analysis of wells in Termit basin, shale interlayers were very low porosity (1-10\%), low permeability (2-50md), high density $(2.35-2.65 \mathrm{~g} / \mathrm{cm} 3)$, large total shale thickness $(100-400 \mathrm{~m})$, with more than $3 \mathrm{~m}$ single layer thickness, large shale ratio $(52-70 \%)$ 。 Shales thickness around Dinga and Moul sags was larger than $200 \mathrm{~m}$, but relatively smaller in the centre of the two sags. This is another evidence of far provenance supply of YS3 sub-formation. Moreover, comprehensive evaluation of cap rock in Yogou formation of Termit basin showed the 1st grade gas cap with very good sealing condition.

\subsection{Influencing factor and oil accumulation model}

Structure-lithologic, Structure-strata, stratigraphy, and sand lens are four kinds of lithologic traps [27], and oil accumulation model of lithologic traps in Termit basin was established according to $13026 \mathrm{~km} \mathrm{2D}$ and 11607 $\mathrm{km}^{2}$ 3D seismic data observation and 62 drilled wells analysis. Except serval favourable and common lithologic traps conditions, i.e., depressing basin evolution, slope paleotopography, near hydrocarbon centre, sand-shale interlayer associations, influencing factors of three types of lithologic traps are different.

\subsubsection{Structure lithology traps}

On the structure high of Yogou slope and Fana uplift, favourable structure features for multiple faults constructed faulted lithology and anticline lithology traps (Table.3 Structure-lithology). These traps were controlled by structure condition and sands-faults allocation. Faults were not only oil-gas migration tunnels, but also lateral sealing surfaces. For large faults, reverse fault blocks were not favourable for oil accumulation as up-dip block jointed with thick and blocky braided river sands in Mandama formation, and oil leaked and escaped from the sands. However, normal fault blocks may be favourable with good sands-faults allocation. For small faults, both normal fault and reverse fault blocks were favourable for oil accumulation. Such as the lithologic trap in normal fault blocks southern Yogou slope, with "convex top - flat bottom" shape of mouth bars and "flat top - convex bottom" of submarine channels showing multiple sands migration. This trap area is $27.5 \mathrm{~km}^{2}$, with $70 \mathrm{~ms}$ amplitude. This kind of trap is more common in the study area, high risk on caprock and sands connection on both sides of faults.

\subsubsection{Structure strata traps}

For structure strata traps, anticline-unconformity and fault-strata overlap are more common (Table.3), controlled by structure background or paleotopography. The former is common in slope belts around depression basin sags, caused by braided delta front sands progradation and vertical staking on local anticlines, with a relatively large scale. Such as the anticline-unconformity trap in southeast Fana uplift, and the area is $24.3 \mathrm{~km}^{2}$, with $173 \mathrm{~ms}$ amplitude (Table3. Anticline-unconformity trap). The main risk in this kind of trap is the sealing ability, and composite evaluation is relatively low. Therefore, it is a favourable type of lithologic trap in this area. The latter is common in slope belt around sags of fault-depression basin or depression basin with inherited faults, caused by braided delta front sands overlapped and then incised by later faults, with a relatively small scale. This kind of trap is very common in Termit basin (Table3. fault-strata trap), and the main risk is caprock and sands connection on both sides of faults, with high risk evaluation.

\subsubsection{Strata traps}

In centre Yogou slope and west Fana uplift near Dinga sag, strata of onlap, downlap, toplap are always obvious, and sands of progradation or retrogradation are very clear. Strata traps are very common in these area, composed with sand lens. In strata traps, sand-shale allocation 
combination on sequence boundary both up and down are very important, including unconformity and strata overlap traps. The two are formed in the process of the progradation or retrogradation of braided delta front sands around the slope of Dinga and Moul depression, controlled by sands shales connection, paleotopography, sands distribution and strata cycle combination. The risk of unconformity trap is whether regional caprocks have or not (Table.3 strata unconformity trap), with low comprehensive evaluation. The risk of strata overlap trap is not only whether regional caprock have or not, but also large or small trap scale, and high comprehensive evaluation. Such as multiple sets of reservoir-caprock combination both vertical and lateral (Table.3 strata overlap trap), was formed by quick strata overlapping of multi-periods braided delta front sands. The sand combinations are thin with large area, more than $20 \mathrm{~km}^{2}$, and low comprehensive evaluation.

\subsubsection{Lithology traps}

Near the centre of Dinga and Moul sags, thin sands of braided delta front flew directly into onshore - shallow sea as up dip pinch out sands or slid down to bathyal sea - deep sea as turbidite sand lens. These sands were string bead or fan shape as point provenance supply, or belt shape as line provenance supply, with thin and fine sands interlaid by thick shales as effective caprocks. However, these sands or traps were discontinuous, and small scale with single one and large scale with combination. Such as in central-east of Fana uplift, these sand lens traps are $36 \mathrm{~km}^{2}$ large area and $270 \mathrm{~ms}$ traps amplitude (Table. 3 sand lens traps), with low risk of comprehensive evaluation. Moreover, up-dip pinch-out traps were caused by braided delta front sands planar migration and good up dip lateral sealing (Table.3 up-dip pinch-out traps), with small scale and high overall evaluation.

\section{Conclusions}

(1) Termit basin, deposited braided delta in Campanian stage of passive rift basin, has characteristics of abundant bar sands supply, quickly changing and frequently migrating submarine channels and mouth bars with progradation and retrogradation BLC cycles, multi-stages stacking pattern in geological history, special paleotopography and faults distribution caused by multi-periods depressing and rifting of basin evolution, and can form a lot types of lithologic strata traps by thin sands and shales interlayers.

(2) Structure-lithology, Structure-strata, stratigraphic and lithology are concluded. Traps influencing factors, i.e., structure geometry, sands distribution, paleotopography, stratigraphy cycling, sand-shale lateral connection, reservoir quality and so on. Structure geometry and sands distribution are very important for the structure-lithology traps; structure geometry and paleotopography are key factors in Structure-strata traps; paleotopography and sand-shale lateral connection can be focused on stratigraphic traps, and these traps risks on regional cap rock quality. Moreover, sands distribution and reservoir quality are key factors for lithology traps, and they risk on reservoir sands distribution.

Table 2. Lithology-strata traps identification and classification (including anticline-lithology and faulted-lithology in structure-lithology traps; anticline unconformity and faulted-strata overlap in structure-strata traps; un-conformity and strata overlap in strata traps; sand lens and up-dip pinch-out in lithology traps)

\begin{tabular}{|c|c|c|c|c|c|}
\hline Trap type & & Trap element & Typical seismic profile & Risk eva & ion \\
\hline \multirow{2}{*}{$\begin{array}{l}\text { Structur } \\
\text { e-litholo } \\
\text { gy }\end{array}$} & $\begin{array}{l}\text { anticline-lith } \\
\text { ology }\end{array}$ & $\begin{array}{lr}\text { area, } & \text { buried } \\
\text { depth, } & \text { closure } \\
\text { amplitude, } & \text { sands } \\
\text { distribution } & \end{array}$ & $\begin{array}{l}\text { Ngourti30 } \\
\text { Xine } 1188\end{array}$ & $\begin{array}{l}\text { S: } 90 \%, \sqrt{ } \\
\text { R: } 90 \%, \sqrt{ } \\
\text { C: } 30 \%, ? \\
\text { M: } 80 \%, \sqrt{ } \\
\text { T: } 80 \%, \sqrt{ } \\
\text { P: } 80 \%, \sqrt{ }\end{array}$ & $\begin{array}{l}\text { Favorable: S, } \\
\text { R, M, T, P; } \\
\text { Unfavorable: } \\
\text { C }\end{array}$ \\
\hline & $\begin{array}{l}\text { Fault } \\
\text { lithology }\end{array}$ & $\begin{array}{l}\text { area, buried } \\
\text { depth, closure } \\
\text { amplitude, } \\
\text { sand-shale } \\
\text { connection }\end{array}$ & Yolou30 & $\begin{array}{l}\text { S: } 90 \%, \sqrt{ } \\
\text { R: } 90 \%, \sqrt{ } \\
\text { C: } 30 \%, ? \\
\text { M: } 80 \%, \sqrt{ } \\
\text { T: } 50 \%, ? \\
\text { P: } 60 \%, ?\end{array}$ & $\begin{array}{l}\text { Favorable: S, } \\
\mathrm{R}, \mathrm{T} \text { (small } \\
\text { fault throw), } \\
\mathrm{M} \text {; } \\
\text { Unfavorable: } \\
\mathrm{C}, \mathrm{T} \text { (large } \\
\text { fault throw), } \mathrm{P}\end{array}$ \\
\hline $\begin{array}{l}\text { Structur } \\
\text { e-strata }\end{array}$ & $\begin{array}{l}\text { anticline } \\
\text { un-conformi } \\
\text { ty }\end{array}$ & $\begin{array}{l}\text { area, buried } \\
\text { depth, closure } \\
\text { amplitude, } \\
\text { paleotopography, } \\
\text { sands distribution }\end{array}$ & $\begin{array}{l}\text { Ngourti3o } \\
\text { Xline } 1143\end{array}$ & $\begin{array}{l}\text { S: } 90 \%, \sqrt{ } \\
\text { R: } 80 \%, \sqrt{ } \\
\text { C: } 30 \%, ? \\
\text { M: } 80 \%, \sqrt{ } \\
\text { T: } 80 \%, \sqrt{ } \\
\text { P: } 80 \%, \sqrt{ }\end{array}$ & $\begin{array}{l}\text { Favorable: S, } \\
\text { M, T, P; } \\
\text { Unfavorable: } \\
\text { C }\end{array}$ \\
\hline
\end{tabular}




\begin{tabular}{|c|c|c|c|c|c|}
\hline & $\begin{array}{l}\text { faulted-strat } \\
\text { a overlap }\end{array}$ & $\begin{array}{l}\text { area, buried } \\
\text { depth, closure } \\
\text { amplitude, } \\
\text { paleotopography, } \\
\text { sand-shale } \\
\text { connection }\end{array}$ & 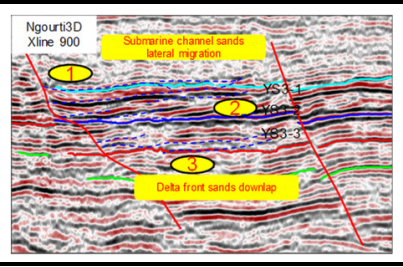 & $\begin{array}{l}\text { S: } 90 \%, \sqrt{ } \\
\text { R: } 80 \%, \sqrt{ } \\
\text { C: } 30 \%, ? \\
\text { M: } 80 \%, \sqrt{ } \\
\text { T: } 50 \%, ? \\
\text { P: } 60 \%, ?\end{array}$ & $\begin{array}{l}\text { Favorable: S, } \\
\mathrm{R}, \mathrm{T} \text { (small } \\
\text { fault throw), } \\
\mathrm{M} ; \\
\text { Unfavorable: } \\
\mathrm{C}, \mathrm{T} \text { (large } \\
\text { fault throw), } \mathrm{P}\end{array}$ \\
\hline \multirow{2}{*}{ Strata } & $\begin{array}{l}\text { un-conformi } \\
\text { ty }\end{array}$ & $\begin{array}{l}\text { sands distribution, } \\
\text { paleo-topography, } \\
\text { sand-shale } \\
\text { connection }\end{array}$ & 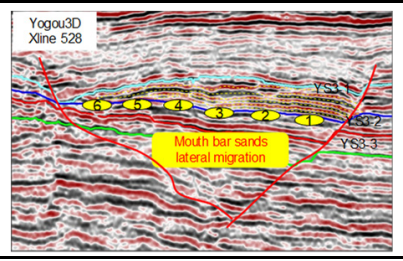 & $\begin{array}{l}\text { S: } 90 \%, \sqrt{ } \\
\text { R: } 80 \%, \sqrt{ } \\
\text { C: } 30 \%, ? \\
\text { M: } 80 \%, \sqrt{ } \\
\text { T: } 80 \%, \sqrt{ } \\
\text { P: } 80 \%, \sqrt{ }\end{array}$ & $\begin{array}{l}\text { Favorable: } \\
\text { S, R, T, M, P; } \\
\text { Unfavorable: } \\
\text { C }\end{array}$ \\
\hline & $\begin{array}{l}\text { strata } \\
\text { overlap }\end{array}$ & $\begin{array}{l}\text { sands distribution, } \\
\text { paleo-topography, } \\
\text { strata evolution }\end{array}$ & 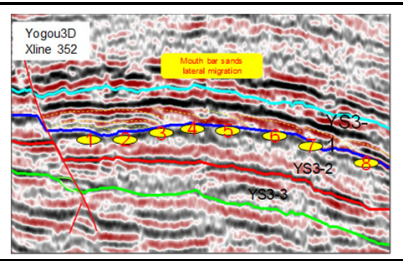 & $\begin{array}{l}\text { S: } 90 \%, \sqrt{ } \\
\text { R: } 80 \%, \sqrt{ } \\
\text { C: } 60 \%, ? \\
\text { M: } 80 \%, \sqrt{ } \\
\text { T: } 70 \%, ? \\
\text { P: } 80 \%, \sqrt{ }\end{array}$ & $\begin{array}{l}\text { Favorable: } \\
\text { S, R, M, P; } \\
\text { Unfavorable: } \\
\text { C, T (small } \\
\text { scale) }\end{array}$ \\
\hline \multirow{2}{*}{ Lithology } & sand lens & $\begin{array}{l}\text { sands distribution, } \\
\text { reservoir quality }\end{array}$ & 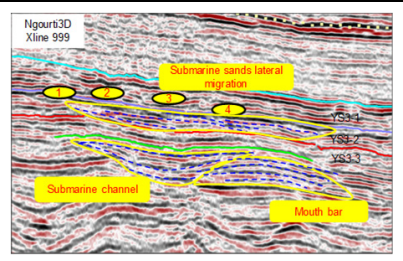 & $\begin{array}{l}\text { S: } 90 \%, \sqrt{ } \\
\text { R: } 70 \%, ? \\
\text { C: } 90 \%, \sqrt{ } \\
\text { M: } 80 \%, \sqrt{ } \\
\text { T: } 70 \%, ? \\
\text { P: } 90 \%, \sqrt{ }\end{array}$ & $\begin{array}{l}\text { Favorable: } \\
\text { S, C, M, P; } \\
\text { Unfavorable: } \\
\text { T (small } \\
\text { scale), R } \\
\text { (porosity } \\
\text { unclear) }\end{array}$ \\
\hline & $\begin{array}{l}\text { up-dip } \\
\text { pinch-out }\end{array}$ & $\begin{array}{l}\text { sands distribution, } \\
\text { reservoir quality, } \\
\text { strata dip angle }\end{array}$ & 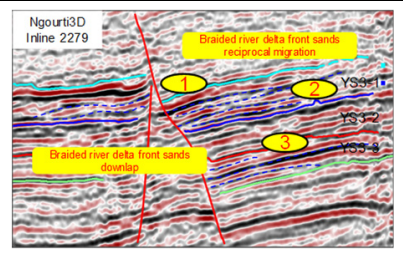 & $\begin{array}{l}\text { S: } 90 \%, \sqrt{ } \\
\text { R: } 70 \%, ? \\
\text { C: } 90 \%, \sqrt{ } \\
\text { M: } 80 \%, \sqrt{ } \\
\text { T: } 70 \%, ? \\
\text { P: } 90 \%, \sqrt{ }\end{array}$ & $\begin{array}{l}\text { Favorable: } \\
\text { S, C, M, P; } \\
\text { Unfavorable: } \\
\text { (small scale), } \\
\text { R (porosity } \\
\text { unclear) }\end{array}$ \\
\hline
\end{tabular}

\section{Acknowledgment}

Supported by National Science and Technology key Project No.29: Target evaluation of overseas key exploration areas and research on selection zones and areas in future (2016ZX05029005)

\section{REFERENCES CITED}

1. M.c.pherson J G, Shanmugan G and Moiola R J. Fan deltas and braid deltas: conceptural problems, In: Fan Deltas: Sedimentology and Tectonic Settings (Eds by Nemec W. and Steel R.J.). Blackie and Son, London, 14-22, 1988.

2. Zhu Xiaomin, Deng Xiuqin, LIU Ziliang, et al. Sedimentary characteristics and model of shallow braided delta in large-scale lacustrine: An example from Triassic Yanchang Formation in Ordos Basin: Earth Science Frontiers, 20, 19-28 (2013)

3. $\mathrm{Yu}$ Xinghe. Clastic hydrocarbon reservoir sedimentology: Petroleum Industry Press, Beijing, 397-402 (2008).

4. Wang Yue, Chen Shiyue, Liang Huiyuan. Sedimentary model of braided delta of the Jurassic in Heshituoluogai Basin: Lithologic reservoirs, 27, 81-86 (2015).
5. Li Shnmin, Song Xinmin, Liu Riqiang, et al. Depositional Models of Regressive and Progressive Shoal Braided Deltas in Wenmi Oilfield: Journal of Jilin University, 41, 665-672 (2011).

6. Zhou Hongrui, Wang Xunlian, Liu Zhirong, et al. Braided delta sediments of the Huangshanjie Formation of Upper Triassic in southern Junggar Basin: Journal of Palaeogeography, 8, 187-198 (2006).

7. Zhou Lihong, Han Guomeng, Mou Zhiquan, et al. Research on hydrocarbon accumulation models of gentle slope belt of half garben - A case study of Qibei slope belt: China Academic Journal Electronic Publishing House, 27, 27-31 (2013).

8. Yang Fan, Yu Xinhe, Li Shengli, et al. Oil/Water Inversion and Its Genetic Mechanism in the Structural-Lithologic Reservoir of Low-Porosity and Low Permeability: Journal of China University of M ining \& Technology, 39, 747-752 (2010).

9. Pang Xiongqi, Chen Dongxia, Zhang Jun. Progress and prospect of research on hydrocarbon accumulation mechanism of subtle reservoirs: 12, 56-62 (2007)

10. Niu Jiayu, Li Qiufen. Discussion on proposition and definition of subtle oil-gas reservoir: Acta Petrolei Sinica, 26, 122-126 (2005).

11. Qiao Hansheng, Wang Mingming. The subtle reservoirs in Bohaiwan basin: Earth Science Frontiers, 7, 496-506 (2000).

12. Levorsen A.I. The obscure and subtle trap: AAPG Bulletin, 50, 2058-2067 (1966). 
13. Zhang Wei, Wu Qiang, Huang Jinli. Exploration of subtle reservoirs in the northern shelf basins of south China sea: Offshore Oil, 26, 20-24 (2006).

14. Zhao Ning. High resolution seismic attribute analysis and lithological trap identification of thin layer braided delta deposits: a case on the Yogou and Sokor formation in the Yogou 3-D aera of Agadem block, Niger: AAPG International Conference \& Exhibition, Melbourne, Australia. Datapages/Search and Discovery Article \#90217 (2015).

15. Lv Mingsheng, Xue Liangqin, Su Yongdi, et al. Rifting Controls on Sequence Stratigraphic Architecture: A Case Study in the Lower Cretaceous of Termit Basin, West African Rift System: Journal of Jilin University, 42, 647-656 (2012).

16. Sheriff R E, 2002. Encyclopedic dictionary of applied geophysics (4th edition): Society of Exploration Geophysicists, 429.

17. Feng $\mathrm{Y}$, Wang $\mathrm{X}$, Chen $\mathrm{S}$, et al. Application of nonlinear discriminate function in oil-gas prediction: Annual Meeting Abstracts: Society Of Exploration Geophysicists, 981-984 (1999).

18. Cooke D, Ball V, Muryanto T, et al. What is the best seismic attribute for quantitative seismic reservoir characterization: Annual Meeting Abstracts: Society Of Exploration Geophysicists, 1588-1591 (1999).

19. Cooke D. Techniques for improving seismic attribute versus plots with synthetic and real data examples from Prudhoe Bay Field: well-log property cross Annual Meeting Abstracts: Society Of Exploration Geophysicists, 69-72 (1999).

20. A R Vrown. Seismic Attributes and Their Classification: The Leading EAEG, 10(1996).

21. Wang Tianqi. Exploration method and application of lithologic oil and gas reservoirs - A case on Banghu area of Qianjiang sag, Jianghan basin (Chengdu University of Technology, Chengdu, 2003).

22. Lin Zhengliang, Wang Hua, Li Hongjing, et al. Current status and progress of seismic sedimentology: Geological Science and Technology Information, 28, 131-137 (2009).

23. Halbouty M. T. The deliberate search for the subtletrap: AAPG Memoir, 32, 351-368 (1982).

24. Connan, J. On time - temperature relation in oil genesis: AAPG Bull , 58, 12 (1974).

25. Lv Yanfang, Fu Guang, Gao Dalin. Study on oil and gas reservoir sealing (Petroleum Industry Press, 1-120, 1996).

26. Fu Guang, Chen Zhangming, Jiang Zhenxue, et al. The sealing of uncomoacted mudstone: China Offshore Oil and Gas, 9, 164-168 (1995).

27. Hu Jianyi, Xu Shubao, Liu Shulei, et al. Non-structure reservoirs (Petroleum Industry Press, Beijing, 1986). 